\title{
MicroRNAs, DNA Damage Response, and Cancer Treatment
}

\author{
Mingyang He, Weiwei Zhou, Chuang Li and Mingxiong Guo * \\ Hubei Key Laboratory of Cell Homeostasis, College of Life Sciences, Wuhan University, Wuhan 430072, China; \\ 2014202040110@whu.edu.cn (M.H.); zhouww@whu.edu.cn (W.Z.); lic93@whu.edu.cn (C.L.) \\ * Correspondence: guomx@whu.edu.cn; Tel./Fax: +86-27-6875-2472
}

Academic Editor: William Chi-shing Cho

Received: 6 October 2016; Accepted: 7 December 2016; Published: 12 December 2016

\begin{abstract}
As a result of various stresses, lesions caused by DNA-damaging agents occur constantly in each cell of the human body. Generally, DNA damage is recognized and repaired by the DNA damage response (DDR) machinery, and the cells survive. When repair fails, the genomic integrity of the cell is disrupted-a hallmark of cancer. In addition, the DDR plays a dual role in cancer development and therapy. Cancer radiotherapy and chemotherapy are designed to eliminate cancer cells by inducing DNA damage, which in turn can promote tumorigenesis. Over the past two decades, an increasing number of microRNAs (miRNAs), small noncoding RNAs, have been identified as participating in the processes regulating tumorigenesis and responses to cancer treatment with radiation therapy or genotoxic chemotherapies, by modulating the DDR. The purpose of this review is to summarize the recent findings on how miRNAs regulate the DDR and discuss the therapeutic functions of miRNAs in cancer in the context of DDR regulation.
\end{abstract}

Keywords: microRNAs; DNA damage response; DNA repair; radiotherapy; chemotherapy

\section{Introduction}

\subsection{DNA Damage Response (DDR) and Cancer}

Each of the $\sim 10^{13}$ cells in the human body is assaulted by tens of thousands of DNA lesions per day [1]. In addition to normal cellular metabolic processes, many physical and chemical agents around us can produce DNA damage. For example, ultraviolet (UV) light and ionizing radiation (IR) are typical physical genotoxic agents and can induce up to $10^{5}$ DNA lesions (pyrimidine dimers and (6-4) photoproducts) per cell per day [2]. IR in sunlight or therapeutic radiation can induce single-strand breaks (SSBs) and double-strand breaks (DSBs) in the backbone of the DNA double helix. Other factors, chemical agents, can cause a variety of forms of DNA damage by inhibiting topoisomerase I and topoisomerase II activity or attaching alkyl groups to bases. These chemical agents are generally present in environmental pollutants (such as smoke, factory fumes, and vehicle exhaust) as well as chemotherapeutic agents (e.g., cisplatin and bleomycin).

In order to confront a variety of DNA lesions and ensure genomic stability, cells trigger the DDR to recognize, transduce, and take measures to attenuate DNA damage. The DDR is a complex network that includes specialized sensor proteins to recognize DNA damage, and transducer proteins to recruit subsequent effector proteins responsible for cell cycle arrest, apoptosis, transcription arrest, and DNA repair [3]. Further, confronted with various DNA lesions, cells will select different DNA repair patterns. For example, nonhomologous end joining (NHEJ) and homologous recombination (HR) are two mechanisms of DSB repair.

The DDR is a double-edged sword with regard to cancer development and therapy. On the one hand, because genomic instability is one of the most pervasive conditions underlying onset of 
tumorigenesis [4], DNA lesions on oncogenes or genes involved in cancer-related processes can initiate tumorigenesis. An impaired DDR that fails to repair DNA lesions may promote tumorigenesis and tumor development. On the other hand, the outcome of the DDR sabotages the work of chemo- and radiotherapy [4].

\subsection{Biogenesis and Function of MicroRNAs (miRNAs)}

Since Victor Ambros and colleagues discovered that miRNA lin-4 had antisense complementarity to multiple sites in the $3^{\prime}$-untranslated region (UTR) of the lin-14 gene and reduced the level of LIN-14 protein without a change in expression of lin-14 mRNA, studies of the regulatory mechanism and functions of these short noncoding RNAs have been carried out by more and more researchers $[5,6]$. The mature miRNAs are about 18-25 nucleotides in length, and their biogenesis consists mainly of transcription by RNA polymerase II/III and processing/maturation by two evolutionarily conserved RNase III enzymes, Drosha and Dicer [7,8]. The majority of miRNAs are transcribed by RNA Pol II as primary miRNAs (pri-miRNAs). Following transcription, the Drosha-DGCR8 microprocessor recognizes and processes pri-miRNAs in the nucleus [9]. This step will generate an approximately 70-nucleotide length precursor miRNA (pre-miRNA), which has atypical hairpin structure. Next, the pre-miRNA is translocated from the nucleus to the cytoplasm by exportin-5, and additional processed by Dicer in cytoplasm [10]. By this step, a mature miRNA is yielded, consisting of functional guide strand and passenger strand [11]. The regulatory functions of miRNAs are accomplished through the RNA-induced silencing complex (RISC). miRNA assembles onto RISC, acting as a guide by base-pairing with target mRNA to negatively regulate mRNA expression [12]. By base-pairing at the $3^{\prime}$-UTR, the coding sequence, and $5^{\prime}$-UTR of the mRNA, miRNAs negatively regulate the stability and translation of mRNA. Owing to the vast number of miRNAs and their multiple target genes, the regulatory functions of miRNAs exist in almost all cellular processes, including proliferation, apoptosis, differentiation, senescence, and cell cycle arrest. A large number of genes in the DDR process are targeted and regulated by miRNAs, and several review articles have described the role of miRNAs in regulating the DDR [13-15]. In the following section, we will describe some miRNA-regulated genes and the multiple diverse functions of miRNAs in the DDR processes (Figure 1).

\section{2. miRNAs Mediate DDR Regulation}

\subsection{Sensors/Mediators/Transducers of DDR}

The DDR is a molecular mechanism that cells have evolved to sense DNA damage, transduce these signals and promote their repair [16]. Acting as a sensor of DSB signaling, the MRE11/RAD50/NSB1 (MRN) complex recruits DDR-related proteins, including ataxia telangiectasia mutated (ATM) and other DDR mediators, to the DSB sites [13,17]. ATM-dependent phosphorylation of histone variant $\mathrm{H} 2 \mathrm{AX}-\gamma \mathrm{H} 2 \mathrm{AX}$ serves as a platform for recruitment of additional DDR factors and enhancement of signaling pathways [17]. In 2009, Lal and colleagues showed that inhibition of H2AX expression and DNA repair in terminally differentiated blood cells is mediated by upregulated miR-24 and also that the miR-24-mediated H2AX suppression rendered hematopoietic cells hypersensitive to DNA-damaging agents [18]. Overexpressed miRNA-138 was also shown to regulate the DDR by inhibiting expression of its target, $\mathrm{H} 2 \mathrm{AX}$, and reducing formation of foci of phosphorylated H2AX [19,20].

Upon the recognition of DNA lesions by sensor/mediator proteins, transducers, such as ATM, ataxia telangiectasia and Rad3 related (ATR), and DNA-dependent protein kinase catalytic subunit (DNA-PKcs) relay, transduce, and amplify the original damage signal to effectors in downstream pathways, including the DNA repair, cell cycle checkpoint, and apoptosis pathways [13]. Some studies have shown, using target prediction programs, that several miRNAs can suppress ATM expression by targeting the $3^{\prime}$-UTR of ATM transcripts. Overexpressed miR-18a in breast cancer cells suppresses ATM expression and its formation of nuclear foci by its downstream substrates H2AX and 53BP1, which reduced the DNA damage repair capacity of cells to irradiation-chemotherapy [21]. miR-421 
has also been described as negatively regulating ATM expression, leading to clinically manifest tumor radiosensitivity [22].

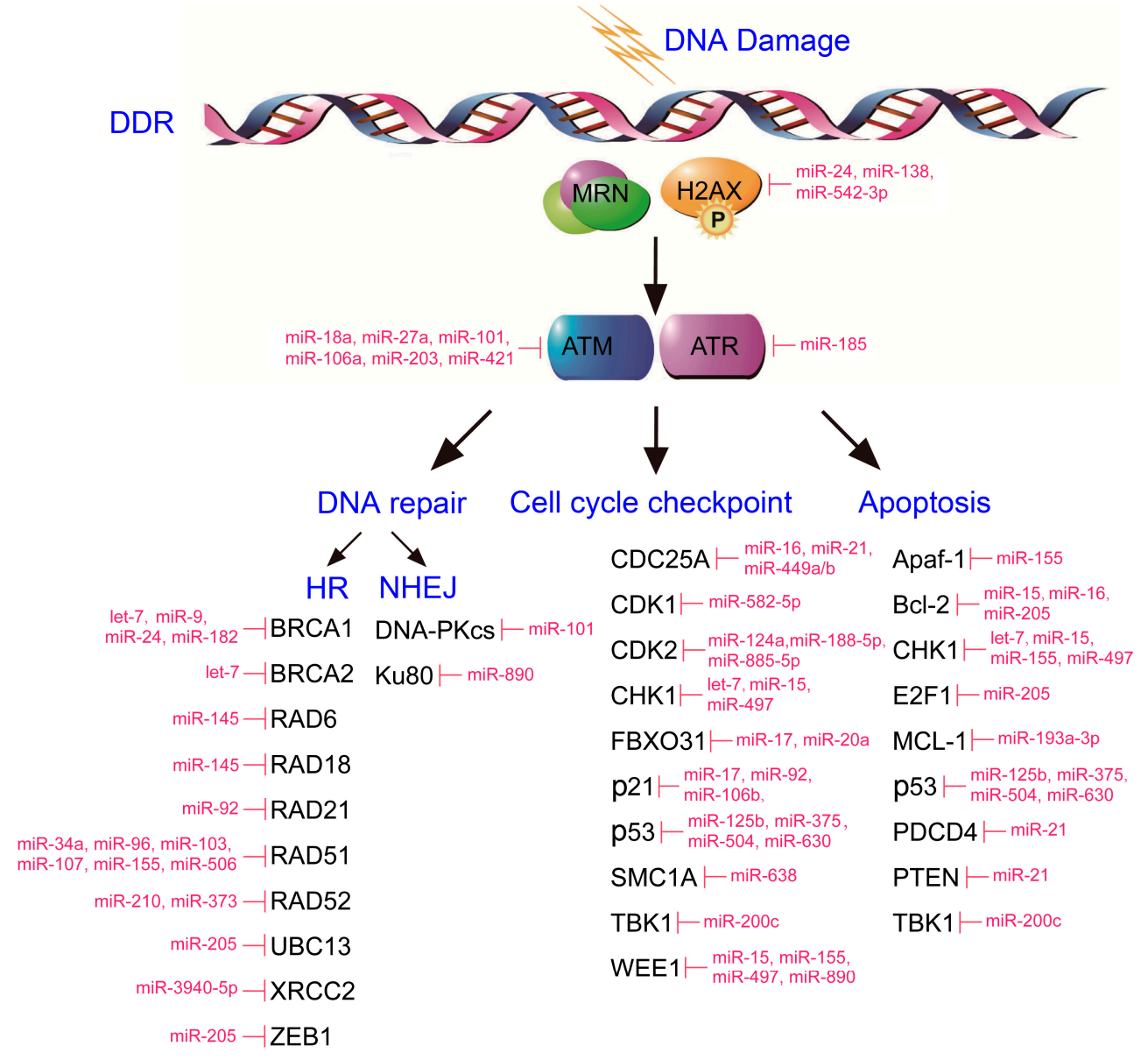

Figure 1. Schematic diagram representing chromosomal DNA and the major components of the DDR signaling pathway (top). Major and minor components of the DDR pathway are arranged in columns based on the aspect of the DDR in which the proteins participate (bottom). miRNAs that interact with individual DDR components are shown in magenta. (1) miRNAs affect DDR sensors: miR-24 [18], miR-138 [20] and miR-542-3p [20] target H2AX; (2) miRNAs affect DDR mediators: miR-421 [22], miR-101 [23], miR-203 [24], miR-18a [25], miR-106a [25] and miR-27a [26] target ATM; and miR-185 [27] targets ATR; (3) miRNAs affect DNA repair by homologous recombination (HR): miR-9 [28], miR-24 [29], miR-182 [30] and let-7 [31] target BRCA1; let-7 [31] targets BRCA2; miR-145 [32] targets RAD6 and RAD18; miR-34a [33], miR-506 [34], miR-107 [35], miR-103 [35], miR-96 [36] and miR-155 [37] target RAD51; miR-92 [38] targets RAD21; miR-210 [39] and miR-373 [39] target RAD52; miR-205 [40] targets ZEB1 and UBC13; and miR-3940-5p [41] targets XRCC2; (4) miRNAs affect DNA repair by nonhomologous end joining (NHEJ): miR-101 [23] targets DNA-PK; and miR-890 [42] targets Ku80; (5) miRNAs affect cell cycle checkpoint: miR-15 [43], miR-497 [44] and let-7 [31] target CHK1; miR-630 [45], miR-504 [46], miR-125b [47] and miR-375 [48] target p53; miR-106b [49], miR-17 [38] and miR-92 [38] target p21; miR-124a [50], miR-885-5p [51], and miR-188-5p [52] target CDK2; miR-582-5p [53] targets CDK1; miR-200c [54] targets TBK1; miR-17 [55] and miR-20a [55] target FBXO31; miR-15 [43], miR-155 [43], miR-497 [44], and miR-890 [42] target WEE1; miR-16 [56], miR-21 [57], and $\mathrm{miR}-449 \mathrm{a} / \mathrm{b}$ [58] target CDC25A; and miR-638 [59] targets SMC1A; and (6) miRNAs affect apoptosis: miR-15 [43], miR-497 [44], let-7 [31], and miR-155 [43] target CHK1; miR-630 [45], miR-504 [46], miR-125b [47], and miR-375 [48] target p53; miR-205 [60] targets E2F1 and BCL-2; miR-16 [61] and miR-15 [62] target BCL-2; miR-193a-3p [63] targets MCL-1; miR-155 [64] targets Apaf-1; miR-200c [54] targets TBK1; and miR-21 [65] targets PTEN and PDCD4. MRN: MRE11/RAD50/NSB1 complex. 
On account of multiple miRNAs involved in regulating the expression of important targets in the DDR signal transduction, which subsequently affects cell cycle arrest and other process, these findings may provide new potential therapeutic targets in tumor therapy.

\subsection{Effectors of DNA Repair}

Multiple DNA-repair mechanisms are necessary to repair the wide variety of DNA-lesion types. Under normal physiological conditions, six major DNA-repair pathways counter DNA lesions: base excision repair, mismatch repair, nucleotide excision repair, translesion DNA synthesis, NHEJ, and HR [4]. Because DSBs are among the most toxic DNA lesions, this type of lesion plays the most important role in cancer therapy, which exploits the toxicity of many chemotherapeutic and radiotherapeutic agents to induce DSBs [17]. NHEJ and HR are the two major DSB repair pathways and function in different phases of the cell cycle.

NHEJ is the major pathway for the repair of DSBs because it can function throughout the cell cycle and not require a homologous chromosome. When DSBs occur, the heterodimers $\mathrm{Ku}(\mathrm{Ku} 70 / \mathrm{Ku} 80)$ rapidly binds to breaks. Ku is capable of interacting with the nuclease, the polymerases and the ligase and acts as a tool belt protein that can stabilize any of a number of enzymatic activities at a DNA end [66]. Knockdown of miR-124 in rats has been proved that can protect against neuronal death and apoptosis by targeting Ku70 [67]. Furthermore, it has recently been shown that Ku80 is overexpressed in lung cancer and overexpressed hsa-miR-526b can downregulate the expression of $\mathrm{Ku} 80$, thus causing G0/G1 phase arrest and significantly suppressing the NSCLC growth in vitro and in vivo [68]. After the binding of the Ku70/Ku80 complex to the DSB, the catalytic subunit DNA-PKcs is recruited and activated. Active DNA-PK phosphorylates a variety of targets, including XRCC4, and together with XRCC4 forms the XRCC4-ligase IV complex to ligate DNA ends [69]. It has been reported that upregulation of miR-101 efficiently reduces the protein levels of DNA-PKcs and ATM via binding to the 3'-UTR of DNA-PKcs mRNA and inhibiting transcription. In this regard, miR-101 can sensitize the tumor cells to radiation in vitro and in vivo by hindering both NHEJ repair and ATM-mediated signal transduction [23].

Unlike the error-prone repair mechanism NHEJ, HR is an error-free pathway that functions only in the late S and G2 phases of the cell cycle as it requires a homologous sequence located on the sister chromatid. HR is initiated by CtIP and is promoted by various proteins, including the MRN complex. RAD51 mediates the invasion of the damaged DNA strand into the undamaged DNA duplex of the sister chromatid. A variety of miRNAs have been found to mediate chemosensitization by impacting RAD51 expression in HR repair mechanism. miR-107 was shown to directly target RAD51 and RAD51D and expression level correlated with PARP inhibitor sensitivity [35,70]. Overexpression of miR-103, miR-222, and miR-96, but not miR-107, decrease RAD51 expression and efficiency of HR repair $[35,36,70]$. BRCA1, a tumor suppressor gene, be recruited at DNA lesions and facilitates DNA repair and cell-cycle regulation as part of the large multisubunit BRCA1-associated genome surveillance complex (BASC). miR-182 expression can impact DNA repair and cellular sensitivity to PARP inhibitors by targeting BRCA1 mRNA and inhibiting its protein expression [30]. miR-99 can also mediate $\mathrm{HR}$ repair by regulating its target, $\mathrm{SNF} 2 \mathrm{H}$, which is required for recruitment of BRCA1 and RAD51 to sites of breaks. Therefore, upregulation of miR-99a reduced DSB repair following IR through repression of SNF2H [71].

\subsection{Effectors of Apoptosis and Cell Cycle Checkpoint}

Tumor cells often exhibit at least one cell cycle checkpoint defect. Therefore, inhibiting the transition of other remaining checkpoints should prevent cell cycle progression and reduce DNA damage repair time, resulting in more tumor cells killed by radiotherapy or chemotherapy [72]. DNA-damage-induced G2/M checkpoints are controlled by a p53-dependent or a p53-independent pathway. In the p53-independent pathway, CHK1/CHK2 blocks activation of cyclinB/CDK1 and causes G2 arrest by controlling the phosphorylation or activity of CDC25A, CDC25B, CDC25C, 
PLK1, and WEE1. Recently, it was reported that inhibition of the miR-15 family failed to increase radioresistance in breast cancer cells. The miR-15 family has been verified to negatively regulate CHK1 and WEE1 at both the mRNA and protein levels, and reduction of CHK1 and WEE1 subsequently prolonged $\gamma-\mathrm{H} 2 \mathrm{AX}$ expression after irradiation, which increased radiosensitivity of cancer cells. In addition to the impact on $\gamma$-H2AX expression, inhibition of WEE1 and CHK1 effectively abrogates G2 arrest [62]. Overexpression of miR-497 and miR-890 can also affect the DDR and enhance cellular sensitivity to cisplatin and IR by promoting WEE1 expression [42,44].

The tumor suppressor p53 plays a central role in both DNA damage-induced G1/S and G2/M checkpoints. ATM/CHK2 or ATR/CHK1 (CHEK1) phosphorylate and stabilize p53, which in turn upregulates p21 to suppress the activity of the cyclin E(A)/CDK2 complex or the cyclinB/CDK1 complex, leading to G1 or G2 arrest. In addition to its extensive function in regulation of cell cycle checkpoints, p53 also plays a critical role in DSB-induced apoptosis. If DNA damage is not repaired in a timely manner, cells will initiate apoptosis before the DNA lesions enlarge and lead to more serious consequences, such as cancers. In response to DSBs, ATM/CHEK2 and ATR/CHK1 (CHEK1) phosphorylate and stabilize p53, resulting in transcriptional activation of pro-apoptotic factors, such as FAS, PUMA, and BAX [15]. Recent studies have determined that several miRNAs are involved in posttranscriptional regulation of p53 by directly binding to the p53 $3^{\prime}$-UTR. miR-25 and miR-30d interact with the $3^{\prime}$-UTR of the human p53 gene and negatively regulate p53 expression. Downregulation of p53 leads to suppression of its target genes, such as p21, BAX and Puma, reducing G1 arrest and apoptosis [73]. Overexpression of miR-504 can mediate apoptosis and cell-cycle arrest in response to stress by downregulating p53 expression by binding to two sites in the p53 3'-UTR [46]. Moreover, miR-7 blocked SMARCD1 expression by binding to two seed regions in the $3^{\prime}$-UTR of SMARCD1 and downregulated SMARCD1 mRNA expression. With chemotherapy, miR-7 downregulated p53-dependent apoptosis-related genes BAX and p21 by interfering with the interaction of SMARCD1 and p53, thereby reducing caspase-3 cleavage and the downstream apoptosis cascades [74].

By disturbed miRNAs expression and further affect cell cycle checkpoint- or apoptosis-related targets expression, tumor cellular radio- or chemo-sensitivity could be changed, which is in favor of efficient and specific tumor therapy.

\section{3. miRNA's Therapeutic Function in Cancer Based on Its Regulation of the DDR}

\subsection{DDR-Related miRNAs as Biomarkers in Clinical Cancer Therapy}

miRNAs have emerged as highly tissue-specific biomarkers, and much evidence shows that miRNA profiles are cell- and tumor-specific [75,76]. For example, expression of miR-155 is significantly higher in lung cancer tissues than in paracancerous and normal tissues [64]. In addition, the average expression level of miR-143 is downregulated in nasopharyngeal carcinoma cells and clinical specimens [77]. Some of these miRNAs that are differentially expressed in tumorous and healthy tissues are reported to target DDR-related genes and regulate cellular DDR processes. miR-338-5p is significantly downregulated in glioblastoma multiforme tumor samples compared with control tissue, and increased cell cycle arrest and apoptosis are observed in miR-338-5p-overexpressing cells [78]. A high level of miR-155 expression in lung cancer cells caused downregulation of expression levels of caspase-9 and Bax, which are the mitochondrial apoptotic pathway proteins [64]. In addition, as an important gene in the HR DNA repair pathway, RAD51 is also targeted by miR-155, and analysis of clinical data for triple negative breast cancer shows that low miR-155 expression level correlates with worse progression-free survival [37]. Moreover, DDR-related miRNA expression levels differ between drug-sensitive and -resistant cancer cells. miR-203 is upregulated in the oxaliplatin-resistant colorectal cancer cell (CRC) lines HT29, HCT116, and RKO. miR-203 regulates a kinase important in the DDR process and ATM expression by binding to its 3'-UTR [24]. miR-18a and miR-31, but not miR-203, are both expressed at a higher level in radiosensitive than in radioresistant cells [79,80]. Hence, the 
identification of altered DDR-related miRNAs affecting the therapeutic response may be helpful in determining the optimal and alternative treatments for cancer patients.

The miR-17-92 cluster has been shown to regulate various cellular processes, including apoptosis and DNA-damage signal transduction [81]. miR-92a is a member of the miR-17-92 cluster. Ohyashiki and colleagues evaluated the clinical relevance of miR-92a in plasma obtained from non-Hodgkin lymphoma patients, and observed that plasma miR-92a values in NHL patients were extremely low, compared with healthy subjects [82]. However, after complete remission in response to chemotherapy (rituximab plus cyclophosphamide, doxorubicin, vincristine and prednisone (CHOP) or CHOP-like regimens), the very low plasma level of miR-92a in NHL patients was increased slightly. Interestingly, the levels of miR-92a decreased again in patients with relapsed disease, suggesting that plasma miR-92a levels correlate with disease conditions in lymphoma patients, and plasma levels of miR-92a might be a useful marker to evaluate therapeutic efficiency or predict tumor recurrence [82].

Overexpression of another DDR-related miRNA, miR-155, increased with progression from normal B cells to monoclonal B-cell lymphocytosis (MBL) to overt chronic lymphocytic leukemia (CLL), and miR-155 expression levels were significantly higher in patients who failed to achieve a complete response than in those who experienced a complete response. Those findings support the use of cellular and plasma levels of miR-155 as biomarkers of the risk of progression in individuals with MBL, as well as to identify patients with CLL who may not respond well to therapy [83].

\subsection{DDR-Related miRNAs as Sensitizers to Radiotherapy or Chemotherapy}

The most common way of treating cancer is to expose the body to agents (including radiotherapy and chemotherapy) that kill cancer cells more efficiently than normal cells. Many cancer drugs employed in the clinic have been used for several decades, and the efficacy of anticancer drugs is highly influenced by the cellular DDR process, whereas recurrent resistance to drug treatments in cancer cells is a key barrier to therapeutic efficiency. Drug-resistant cancer cells can proliferate exponentially, become more aggressive, and have a higher incidence of aggressive metastasis to other organs. Drug resistance is classified in two ways. The first of these is intrinsic resistance, whereby tumors are resistant prior to treatment and, therefore, the drugs do not effectively treat the tumor even with initial early diagnosis and treatment. Another form of resistance is acquired resistance, which occurs despite an initial positive response to therapy [84]. Because of the key role of miRNAs in targeting and regulating multiple genes involved in the DDR, modulation of endogenous miRNA expression may be a very attractive strategy to overcome radio-/chemoresistance. The most important miRNAs and their target DDR genes involved in anticancer drug response are listed in Table 1.

In the previous section, we pointed out that miR-203, miR-18a, and miR-31 are all differentially expressed in sensitive and resistant cells. Further, several DDR-related miRNAs were found to be downregulated and to modulate sensitivity to chemotherapy. miR-152 expression was dramatically downregulated in the cisplatin-resistant cell lines A2780/CP70 and SKOV3/DDP compared with their respective parental cells. Overexpression of miR-152 sensitized cisplatin-resistant ovarian cancer cells by reducing cisplatin-induced autophagy and enhancing cisplatin-induced apoptosis and inhibition of cell proliferation [85]. Another study also found reduced expression of miR-15 family members (miR-15a, miR-15b, miR-16, miR-195, miR-424, and miR-497) and miR-155 in cisplatin-resistant cells. Ectopic expression of the two miRNAs sensitizes the cells to cisplatin-induced apoptosis by targeting WEE1 and CHK1 (CHEK1) kinases [43]. In addition to sensitivity to chemotherapy, specific miRNAs that sensitize or protect cells from radiation have also been reported recently. For instance, miR-205 is downregulated in radioresistant subpopulations of breast cancer cells. Because of a positive correlation between miR-205 expression and radiosensitivity, therapeutic delivery of miR-205 mimics via nanoliposomes in a xenograft modelsensitized the tumor to radiation [40]. These results highlight a potential strategy whereby miRNA levels may be altered by administration of exogenous agents, such as mimics or anti-miRs, to sensitize cancer cells to radio-/chemotherapy and overcome resistance. 
Table 1. Summary of miRNAs and their target DDR genes involved in response to anticancer treatment.

\begin{tabular}{|c|c|c|c|c|c|}
\hline Cancer & miRNA & Target(s) & Therapy & Effects & References \\
\hline \multirow[t]{7}{*}{ Breast } & miR-18a & ATM & IR & Radiosensitivity & [21] \\
\hline & miR-155 & RAD51 & IR & Radiosensitivity & [37] \\
\hline & miR-107 & RAD51 & PARP inhibitor & Chemosensitivity & [35] \\
\hline & miR-182 & BRCA1 & IR & Radiosensitivity & [30] \\
\hline & miR-34a & Bcl-2 & Docetaxel & Chemoresistance & [86] \\
\hline & miR-21 & PTEN and PDCD4 & Chemotherapy & Chemoresistance & {$[87]$} \\
\hline & $\operatorname{miR}-125 b$ & BAK1 & Paclitaxel & Chemoresistance & [47] \\
\hline \multirow[t]{6}{*}{ Lung } & miR-138 & $\mathrm{H} 2 \mathrm{AX}$ & IR & Radiosenstivity & [19] \\
\hline & miR-101 & ATM & IR & Radiosensitivity & [88] \\
\hline & miR-497 & Bcl-2 & Chemotherapy & Chemosensitivity & [89] \\
\hline & miR-34a & RAD51 & IR & Radiosensivity & [33] \\
\hline & miR-155 & Apaf-1 & Chemotherapy & Chemorisistance & [64] \\
\hline & miR-141 & PDCD4 & Cisplatin & Chemoresistance & [90] \\
\hline \multirow[t]{3}{*}{ Ovarian } & miR-506 & RAD51 & Chemotherapy & Chemosensitivity & [34] \\
\hline & miR-152 & ATG14 & Cisplatin & Chemosensitivity & [85] \\
\hline & miR-31 & KCNMA1 & Cisplatin & Chemoresistance & [91] \\
\hline \multirow[t]{2}{*}{ Hepatoma } & $\operatorname{miR}-16$ & Bcl-2 & $\begin{array}{l}\text { Epigallocatechin } \\
\text { gallate }\end{array}$ & Chemosensitivity & {$[61]$} \\
\hline & miR-210 & AIFM3 & IR & Radioresistance & [92] \\
\hline \multirow[t]{2}{*}{ Colorectal } & miR-145 & RAD18 & 5-FU & Chemosensitivity & [32] \\
\hline & miR-203 & ATM & Oxaliplatin & Chemoresistance & [24] \\
\hline \multirow[t]{3}{*}{ Glioblastoma } & miR-100 & ATM & IR & Radioresistance & [93] \\
\hline & miR-338-5P & RHEB & IR & Radiosensitivity & [78] \\
\hline & $\operatorname{miR}-181 b$ & SENP2 & IR & Radioresistance & [87] \\
\hline $\begin{array}{c}\text { Renal } \\
\text { carcinoma }\end{array}$ & miR-185 & ATR & IR & Radiosensitivity & [27] \\
\hline \multirow{2}{*}{ Prostate } & miR-744-3P & RAD23B & IR & Radiosensitivity & [42] \\
\hline & miR-890 & MAD2L2, WEE1, XPC & IR & Radiosensitivity & [42] \\
\hline Cervical & miR-145 & HLTF & IR & Radiosensitivity & [94] \\
\hline Bladder & miR-193a-3P & HOXC9 & Chemotherapy & Chemoresistance & [95] \\
\hline Hematopoietic & miR-24 & $\mathrm{H} 2 \mathrm{AX}$ & Cisplatin & Chemosensitivity & [96] \\
\hline
\end{tabular}

Although miRNA expression profiles differ between resistant and sensitive cancers, environmental stressors can influence miRNA expression in any cancer type. Many studies have revealed that expression levels of several miRNAs change significantly upon radiotherapy or chemotherapy, and do so reproducibly across various cell types. For example, almost all of the miR-15 family miRNAs (miR-15a/b, miR-195, miR-424, and miR-497) were downregulated across a number of different cell lines, including endothelial cells, non-small cell lung cancer (NSCLC) cells, and lymphoblasts [97], whereas miR-148b was repressed by IR in endothelial cells, but induced by IR in non-Hodgkin lymphoma $[98,99]$. Moreover, upregulation of miR-21 is observed in both IR-and doxycycline-stimulated cells $[65,100]$. The variability in drug-induced changes in expression suggests that miRNA expression is modified with exposure to anticancer drugs, and expression levels affect the response to anticancer drugs based on their involvement in DDR-regulatory mechanisms at different levels and through many pathways.

Acting as tumor suppressors, let-7 family miRNAs strongly contribute to the regulation of DDR and cell proliferation and are expressed in many tumors [101]. Weidhaas' and other groups have revealed that the expression of let-7 miRNAs is modified upon irradiation in various cancer cells, such as glioblastoma and NSCLC cells [102-104]. The modified expression of let-7 miRNAs following IR is dependent on p53, which is a key protein in the IR-activated ATM signaling pathway [105]. Further, miR-34a, which is upregulated after exposure to IR or etoposide, is another p53 target. miR-34a functions downstream of the p53 pathway as a tumor suppressor and is involved in regulating cell cycle arrest and apoptosis $[106,107]$. In addition to miR-34, it is well established that miR-21 targets 
many genes (Cdc25A, pAKt, PTEN) in the cell cycle arrest, DDR, and apoptotic pathways, and is consistently upregulated upon IR in a variety of normal and cancer cell lines [108,109].

Consistent with the intimate connection between DDR-related miRNAs and drug resistance, the combined use of DDR-related miRNAs and radio- or chemotherapy has been demonstrated to increase therapeutic efficiency. It has been reported that, by encapsulating miR-34a mimics with liposomes and delivering it into mice, the levels of miR-34a in tumors were increased and the mRNA levels of several miR-34a targets were decreased [110]. In addition, Conde and coworkers have successfully targeted and silenced miR-21 expression by Gold-nanobeacon in pancreatic cancer cell [111]. Moreover, intravenously delivered miR-16 mimics are also currently under Phase I clinical trials for patients with MPM (Malignant Pleural Mesothelioma) and NSCLC (Non-Small Cell Lung Cancer), and preliminary data show manageable safety profile in five patients [112]. Thus, extraneously changing the level of miRNAs can be realized, and miRNA-based therapy might bring new options to cancer treatment.

\section{Conclusions}

In summary, miRNAs are involved in regulating almost every aspect of the DDR; even only one miRNA can mediate multiple targets in the DDR signaling pathway, DNA repair, cell cycle arrest, and apoptosis. This means that miRNA-mediated DDR is a significant and complicated regulatory process. Finding the significant role of miRNAs in DDR and radio- or chemotherapy may provide a new way for us to use miRNAs as potential tools, biomarkers or sensitizers in cancer treatment. Nevertheless, because of the complicated network regulating the interactions of miRNAs and their target genes, much research is needed in the future to clarify the correlation between miRNAs and the DDR.

Acknowledgments: This work was supported by National Natural Science Foundation of China Grant (31271511 to Mingxiong Guo) and Fundamental Research Funds for the Central Universities Grant (2042014KF0243 to Mingxiong Guo).

Author Contributions: Mingxiong Guo and Mingyang He designed this review; Mingyang He, Weiwei Zhou and Chuang Li wrote the manuscript; and Mingxiong Guo revised this manuscript.

Conflicts of Interest: The authors declare no conflict of interest.

\section{References}

1. Lindahl, T.; Barnes, D.E. Repair of endogenous DNA damage. Cold Spring Harb. Symp. Quant. Biol. 2000, 65, 127-133. [CrossRef] [PubMed]

2. Hoeijmakers, J.H. DNA damage, aging, and cancer. N. Eng. J. Med. 2009, 361, 1475-1485. [CrossRef] [PubMed]

3. Khanna, K.K.; Jackson, S.P. DNA double-strand breaks: Signaling, repair and the cancer connection. Nat. Genet. 2001, 27, 247-254. [CrossRef] [PubMed]

4. Tian, H.; Gao, Z.; Li, H.; Zhang, B.; Wang, G.; Zhang, Q.; Pei, D.; Zheng, J. DNA damage response-A double-edged sword in cancer prevention and cancer therapy. Cancer Lett. 2015, 358, 8-16. [CrossRef] [PubMed]

5. Bartel, D.P. MicroRNAs: Genomics, biogenesis, mechanism, and function. Cell 2004, 116, 281-297. [CrossRef]

6. Lee, R.C.; Feinbaum, R.L.; Ambros, V. The C. elegans heterochronic gene lin-4 encodes small RNAs with antisense complementarity to lin-14. Cell 1993, 75, 843-854. [CrossRef]

7. Carthew, R.W.; Sontheimer, E.J. Origins and mechanisms of miRNAs and siRNAs. Cell 2009, 136, $642-655$. [CrossRef] [PubMed]

8. Bushati, N.; Cohen, S.M. MicroRNA functions. Annu. Rev. Cell Dev. Biol. 2007, 23, 175-205. [CrossRef] [PubMed]

9. Lee, Y.; Ahn, C.; Han, J.; Choi, H.; Kim, J.; Yim, J.; Lee, J.; Provost, P.; Radmark, O.; Kim, S.; et al. The nuclear RNase III Drosha initiates microRNA processing. Nature 2003, 425, 415-419. [CrossRef] [PubMed]

10. Yi, R.; Qin, Y.; Macara, I.G.; Cullen, B.R. Exportin-5 mediates the nuclear export of pre-microRNAs and short hairpin RNAs. Genes Dev. 2003, 17, 3011-3016. [CrossRef] [PubMed] 
11. Cai, X.; Hagedorn, C.H.; Cullen, B.R. Human microRNAs are processed from capped, polyadenylated transcripts that can also function as mRNAs. RNA 2004, 10, 1957-1966. [CrossRef] [PubMed]

12. Macfarlane, L.A.; Murphy, P.R. MicroRNA: Biogenesis, function and role in cancer. Curr. Genom. 2010, 11, 537-561. [CrossRef] [PubMed]

13. Han, C.; Wan, G.; Langley, R.R.; Zhang, X.; Lu, X. Crosstalk between the DNA damage response pathway and microRNAs. Cell. Mol. Life Sci. 2012, 69, 2895-2906. [CrossRef] [PubMed]

14. Wan, G.; Mathur, R.; Hu, X.; Zhang, X.; Lu, X. miRNA response to DNA damage. Trends Biochem. Sci. 2011, 36, 478-484. [CrossRef] [PubMed]

15. Hu, H.; Gatti, R.A. MicroRNAs: New players in the DNA damage response. J. Mol. Cell Biol. 2011, 3, 151-158. [CrossRef] [PubMed]

16. Harper, J.W.; Elledge, S.J. The DNA damage response: Ten years after. Mol. Cell 2007, 28, 739-745. [CrossRef] [PubMed]

17. Goldstein, M.; Kastan, M.B. The DNA damage response: Implications for tumor responses to radiation and chemotherapy. Annu. Rev. Med. 2015, 66, 129-143. [CrossRef] [PubMed]

18. Lal, A.; Pan, Y.; Navarro, F.; Dykxhoorn, D.M.; Moreau, L.; Meire, E.; Bentwich, Z.; Lieberman, J.; Chowdhury, D. miR-24-mediated downregulation of H2AX suppresses DNA repair in terminally differentiated blood cells. Nat. Struct. Mol. Biol. 2009, 16, 492-498. [CrossRef] [PubMed]

19. Yang, H.; Luo, J.; Liu, Z.; Zhou, R.; Luo, H. MicroRNA-138 regulates DNA damage response in small cell lung cancer cells by directly targeting H2AX. Cancer Investig. 2015, 33, 126-136. [CrossRef] [PubMed]

20. Wang, Y.; Huang, J.W.; Li, M.; Cavenee, W.K.; Mitchell, P.S.; Zhou, X.; Tewari, M.; Furnari, F.B.; Taniguchi, T. MicroRNA-138 modulates DNA damage response by repressing histone H2AX expression. Mol. Cancer Res. 2011, 9, 1100-1111. [CrossRef] [PubMed]

21. Song, L.; Lin, C.; Wu, Z.; Gong, H.; Zeng, Y.; Wu, J.; Li, M.; Li, J. miR-18a impairs DNA damage response through downregulation of ataxia telangiectasia mutated (ATM) kinase. PLoS ONE 2011, 6, e25454. [CrossRef] [PubMed]

22. Mansour, W.Y.; Bogdanova, N.V.; Kasten-Pisula, U.; Rieckmann, T.; Kocher, S.; Borgmann, K.; Baumann, M.; Krause, M.; Petersen, C.; Hu, H.; et al. Aberrant overexpression of miR-421 downregulates ATM and leads to a pronounced DSB repair defect and clinical hypersensitivity in SKX squamous cell carcinoma. Radiother. Oncol. 2013, 106, 147-154. [CrossRef] [PubMed]

23. Yan, D.; Ng, W.L.; Zhang, X.; Wang, P.; Zhang, Z.; Mo, Y.Y.; Mao, H.; Hao, C.; Olson, J.J.; Curran, W.J.; et al. Targeting DNA-pkcs and ATM with miR-101 sensitizes tumors to radiation. PLoS ONE 2010, 5, e11397. [CrossRef] [PubMed]

24. Zhou, Y.; Wan, G.; Spizzo, R.; Ivan, C.; Mathur, R.; Hu, X.; Ye, X.; Lu, J.; Fan, F.; Xia, L.; et al. miR-203 induces oxaliplatin resistance in colorectal cancer cells by negatively regulating ATM kinase. Mol. Oncol. 2014, 8, 83-92. [CrossRef] [PubMed]

25. Guo, X.; Yang, C.; Qian, X.; Lei, T.; Li, Y.; Shen, H.; Fu, L.; Xu, B. Estrogen receptor $\alpha$ regulates ATM expression through miRNAs in breast cancer. Clin. Cancer Res. 2013, 19, 4994-5002. [CrossRef] [PubMed]

26. Di Francesco, A.; de Pitta, C.; Moret, F.; Barbieri, V.; Celotti, L.; Mognato, M. The DNA-damage response to $\gamma$-radiation is affected by miR-27a in A549 cells. Int. J. Mol. Sci. 2013, 14, 17881-17896. [CrossRef] [PubMed]

27. Wang, J.; He, J.; Su, F.; Ding, N.; Hu, W.; Yao, B.; Wang, W.; Zhou, G. Repression of atr pathway by miR-185 enhances radiation-induced apoptosis and proliferation inhibition. Cell Death Dis. 2013, 4, e699. [CrossRef] [PubMed]

28. Sun, C.; Li, N.; Yang, Z.; Zhou, B.; He, Y.; Weng, D.; Fang, Y.; Wu, P.; Chen, P.; Yang, X.; et al. miR-9 regulation of BRCA1 and ovarian cancer sensitivity to cisplatin and PARP inhibition. J. Natl. Cancer Inst. 2013, 105, 1750-1758. [CrossRef] [PubMed]

29. Lal, A.; Navarro, F.; Maher, C.A.; Maliszewski, L.E.; Yan, N.; O’Day, E.; Chowdhury, D.; Dykxhoorn, D.M.; Tsai, P.; Hofmann, O.; et al. miR-24 inhibits cell proliferation by targeting E2F2, MYC, and other cell-cycle genes via binding to "seedless" 3'UTR microRNA recognition elements. Mol. Cell 2009, 35, 610-625. [CrossRef] [PubMed]

30. Moskwa, P.; Buffa, F.M.; Pan, Y.; Panchakshari, R.; Gottipati, P.; Muschel, R.J.; Beech, J.; Kulshrestha, R.; Abdelmohsen, K.; Weinstock, D.M.; et al. miR-182-mediated downregulation of BRCA1 impacts DNA repair and sensitivity to PARP inhibitors. Mol. Cell 2011, 41, 210-220. [CrossRef] [PubMed] 
31. Johnson, C.D.; Esquela-Kerscher, A.; Stefani, G.; Byrom, M.; Kelnar, K.; Ovcharenko, D.; Wilson, M.; Wang, X.; Shelton, J.; Shingara, J.; et al. The let-7 microRNA represses cell proliferation pathways in human cells. Cancer Res. 2007, 67, 7713-7722. [CrossRef] [PubMed]

32. Liu, R.L.; Dong, Y.; Deng, Y.Z.; Wang, W.J.; Li, W.D. Tumor suppressor miR-145 reverses drug resistance by directly targeting DNA damage-related gene RAD18 in colorectal cancer. Tumour Biol. 2015, 36, 5011-5019. [CrossRef] [PubMed]

33. Cortez, M.A.; Valdecanas, D.; Niknam, S.; Peltier, H.J.; Diao, L.; Giri, U.; Komaki, R.; Calin, G.A.; Gomez, D.R.; Chang, J.Y.; et al. In vivo delivery of miR-34a sensitizes lung tumors to radiation through RAD51 regulation. Mol. Ther.-Nucleic Acids 2015, 4, e270. [CrossRef] [PubMed]

34. Liu, G.; Yang, D.; Rupaimoole, R.; Pecot, C.V.; Sun, Y.; Mangala, L.S.; Li, X.; Ji, P.; Cogdell, D.; Hu, L.; et al. Augmentation of response to chemotherapy by microRNA-506 through regulation of RAD51 in serous ovarian cancers. J. Natl. Cancer Inst. 2015. [CrossRef] [PubMed]

35. Huang, J.W.; Wang, Y.; Dhillon, K.K.; Calses, P.; Villegas, E.; Mitchell, P.S.; Tewari, M.; Kemp, C.J.; Taniguchi, T. Systematic screen identifies miRNAs that target RAD51 and RAD51D to enhance chemosensitivity. Mol. Cancer Res. 2013, 11, 1564-1573. [CrossRef] [PubMed]

36. Wang, Y.; Huang, J.W.; Calses, P.; Kemp, C.J.; Taniguchi, T. miR-96 downregulates REV1 and RAD51 to promote cellular sensitivity to cisplatin and PARP inhibition. Cancer Res. 2012, 72, 4037-4046. [CrossRef] [PubMed]

37. Gasparini, P.; Lovat, F.; Fassan, M.; Casadei, L.; Cascione, L.; Jacob, N.K.; Carasi, S.; Palmieri, D.; Costinean, S.; Shapiro, C.L.; et al. Protective role of miR-155 in breast cancer through RAD51 targeting impairs homologous recombination after irradiation. Proc. Natl. Acad. Sci. USA 2014, 111, 4536-4541. [CrossRef] [PubMed]

38. Zhao, J.; Fu, W.; Liao, H.; Dai, L.; Jiang, Z.; Pan, Y.; Huang, H.; Mo, Y.; Li, S.; Yang, G.; et al. The regulatory and predictive functions of miR-17 and miR-92 families on cisplatin resistance of non-small cell lung cancer. BMC Cancer 2015. [CrossRef] [PubMed]

39. Crosby, M.E.; Kulshreshtha, R.; Ivan, M.; Glazer, P.M. MicroRNA regulation of DNA repair gene expression in hypoxic stress. Cancer Res. 2009, 69, 1221-1229. [CrossRef] [PubMed]

40. Zhang, P.; Wang, L.; Rodriguez-Aguayo, C.; Yuan, Y.; Debeb, B.G.; Chen, D.; Sun, Y.; You, M.J.; Liu, Y.; Dean, D.C.; et al. miR-205 acts as a tumour radiosensitizer by targeting ZEB1 and UBC13. Nat. Commun. 2014. [CrossRef] [PubMed]

41. Li, Y.; Hu, G.; Li, P.; Tang, S.; Zhang, J.; Jia, G. miR-3940-5p enhances homologous recombination after DSB in $\mathrm{Cr}(\mathrm{VI})$ exposed 16HBE cell. Toxicology 2016, 344, 1-6. [CrossRef] [PubMed]

42. Hatano, K.; Kumar, B.; Zhang, Y.; Coulter, J.B.; Hedayati, M.; Mears, B.; Ni, X.; Kudrolli, T.A.; Chowdhury, W.H.; Rodriguez, R.; et al. A functional screen identifies miRNAs that inhibit DNA repair and sensitize prostate cancer cells to ionizing radiation. Nucleic Acids Res. 2015, 43, 4075-4086. [CrossRef] [PubMed]

43. Pouliot, L.M.; Chen, Y.C.; Bai, J.; Guha, R.; Martin, S.E.; Gottesman, M.M.; Hall, M.D. Cisplatin sensitivity mediated by WEE1 and CHK1 is mediated by miR-155 and the miR-15 family. Cancer Res. 2012, 72, 5945-5955. [CrossRef] [PubMed]

44. Soriano, A.; Paris-Coderch, L.; Jubierre, L.; Martinez, A.; Zhou, X.; Piskareva, O.; Bray, I.; Vidal, I.; Almazan-Moga, A.; Molist, C.; et al. MicroRNA-497 impairs the growth of chemoresistant neuroblastoma cells by targeting cell cycle, survival and vascular permeability genes. Oncotarget 2016, 7, 9271-9287. [PubMed]

45. Galluzzi, L.; Morselli, E.; Vitale, I.; Kepp, O.; Senovilla, L.; Criollo, A.; Servant, N.; Paccard, C.; Hupe, P.; Robert, T.; et al. miR-181A and miR-630 regulate cisplatin-induced cancer cell death. Cancer Res. 2010, 70, 1793-1803. [CrossRef] [PubMed]

46. Hu, W.; Chan, C.S.; Wu, R.; Zhang, C.; Sun, Y.; Song, J.S.; Tang, L.H.; Levine, A.J.; Feng, Z. Negative regulation of tumor suppressor p53 by microRNA miR-504. Mol. Cell 2010, 38, 689-699. [CrossRef] [PubMed]

47. Zhou, M.; Liu, Z.; Zhao, Y.; Ding, Y.; Liu, H.; Xi, Y.; Xiong, W.; Li, G.; Lu, J.; Fodstad, O.; et al. MicroRNA-125b confers the resistance of breast cancer cells to paclitaxel through suppression of pro-apoptotic Bcl-2 antagonist killer 1 (BAK1) expression. J. Biol. Chem. 2010, 285, 21496-21507. [CrossRef] [PubMed]

48. Liu, Y.; Xing, R.; Zhang, X.; Dong, W.; Zhang, J.; Yan, Z.; Li, W.; Cui, J.; Lu, Y. miR-375 targets the p53 gene to regulate cellular response to ionizing radiation and etoposide in gastric cancer cells. DNA Repair 2013, 12, 741-750. [CrossRef] [PubMed] 
49. Ivanovska, I.; Ball, A.S.; Diaz, R.L.; Magnus, J.F.; Kibukawa, M.; Schelter, J.M.; Kobayashi, S.V.; Lim, L.; Burchard, J.; Jackson, A.L.; et al. MicroRNAs in the miR-106B family regulate p21/CDKN1A and promote cell cycle progression. Mol. Cell. Biol. 2008, 28, 2167-2174. [CrossRef] [PubMed]

50. Nakamachi, Y.; Kawano, S.; Takenokuchi, M.; Nishimura, K.; Sakai, Y.; Chin, T.; Saura, R.; Kurosaka, M.; Kumagai, S. MicroRNA-124a is a key regulator of proliferation and monocyte chemoattractant protein 1 secretion in fibroblast-like synoviocytes from patients with rheumatoid arthritis. Arthritis Rheum. 2009, 60, 1294-1304. [CrossRef] [PubMed]

51. Afanasyeva, E.A.; Mestdagh, P.; Kumps, C.; Vandesompele, J.; Ehemann, V.; Theissen, J.; Fischer, M.; Zapatka, M.; Brors, B.; Savelyeva, L.; et al. MicroRNA miR-885-5p targets CDK2 and MCM5, activates p53 and inhibits proliferation and survival. Cell Death Diff. 2011, 18, 974-984. [CrossRef] [PubMed]

52. Wu, J.; Lv, Q.; He, J.; Zhang, H.; Mei, X.; Cui, K.; Huang, N.; Xie, W.; Xu, N.; Zhang, Y. MicroRNA-188 suppresses G1/S transition by targeting multiple cyclin/CDK complexes. Cell Commun. Signal. 2014, 12, 66. [CrossRef] [PubMed]

53. Zhang, Y.; Huang, W.; Ran, Y.; Xiong, Y.; Zhong, Z.; Fan, X.; Wang, Z.; Ye, Q. miR-582-5p inhibits proliferation of hepatocellular carcinoma by targeting CDK1 and AKT3. Tumour Biol. 2015, 36, 8309-8316. [CrossRef] [PubMed]

54. Lin, J.; Liu, C.; Gao, F.; Mitchel, R.E.; Zhao, L.; Yang, Y.; Lei, J.; Cai, J. miR-200c enhances radiosensitivity of human breast cancer cells. J. Cell. Biochem. 2013, 114, 606-615. [CrossRef] [PubMed]

55. Zhang, X.; Kong, Y.; Xu, X.; Xing, H.; Zhang, Y.; Han, F.; Li, W.; Yang, Q.; Zeng, J.; Jia, J.; et al. F-box protein FBXO31 is down-regulated in gastric cancer and negatively regulated by miR-17 and miR-20a. Oncotarget 2014, 5, 6178-6190. [CrossRef] [PubMed]

56. Pothof, J.; Verkaik, N.S.; van, I.W.; Wiemer, E.A.; Ta, V.T.; van der Horst, G.T.; Jaspers, N.G.; van Gent, D.C.; Hoeijmakers, J.H.; Persengiev, S.P. MicroRNA-mediated gene silencing modulates the UV-induced DNA-damage response. EMBO J. 2009, 28, 2090-2099. [CrossRef] [PubMed]

57. De Oliveira, P.E.; Zhang, L.; Wang, Z.; Lazo, J.S. Hypoxia-mediated regulation of CDC25A phosphatase by p21 and miR-21. Cell Cycle 2009, 8, 3157-3164. [CrossRef] [PubMed]

58. Yang, X.; Feng, M.; Jiang, X.; Wu, Z.; Li, Z.; Aau, M.; Yu, Q. miR-449a and miR-449b are direct transcriptional targets of E2F1 and negatively regulate PRB-E2F1 activity through a feedback loop by targeting CDK6 and CDC25A. Genes Dev. 2009, 23, 2388-2393. [CrossRef] [PubMed]

59. He, M.; Lin, Y.; Tang, Y.; Liu, Y.; Zhou, W.; Li, C.; Sun, G.; Guo, M. miR-638 suppresses DNA damage repair by targeting SMC1A expression in terminally differentiated cells. Aging 2016, 8, 1442-1456. [CrossRef] [PubMed]

60. Alla, V.; Kowtharapu, B.S.; Engelmann, D.; Emmrich, S.; Schmitz, U.; Steder, M.; Putzer, B.M. E2F1 confers anticancer drug resistance by targeting $\mathrm{ABC}$ transporter family members and Bcl-2 via the p73/DNP73-miR-205 circuitry. Cell Cycle 2012, 11, 3067-3078. [CrossRef] [PubMed]

61. Tsang, W.P.; Kwok, T.T. Epigallocatechin gallate up-regulation of miR-16 and induction of apoptosis in human cancer cells. J. Nutr. Biochem. 2010, 21, 140-146. [CrossRef] [PubMed]

62. Mei, Z.; Su, T.; Ye, J.; Yang, C.; Zhang, S.; Xie, C. The miR-15 family enhances the radiosensitivity of breast cancer cells by targeting G2 checkpoints. Radiat. Res. 2015, 183, 196-207. [CrossRef] [PubMed]

63. Kwon, J.E.; Kim, B.Y.; Kwak, S.Y.; Bae, I.H.; Han, Y.H. Ionizing radiation-inducible microRNA miR-193a-3p induces apoptosis by directly targeting MCL-1. Apoptosis 2013, 18, 896-909. [CrossRef] [PubMed]

64. Zang, Y.S.; Zhong, Y.F.; Fang, Z.; Li, B.; An, J. miR-155 inhibits the sensitivity of lung cancer cells to cisplatin via negative regulation of APAF-1 expression. Cancer Gene Ther. 2012, 19, 773-778. [CrossRef] [PubMed]

65. Niu, J.; Shi, Y.; Tan, G.; Yang, C.H.; Fan, M.; Pfeffer, L.M.; Wu, Z.H. DNA damage induces NF-kB-dependent microRNA-21 up-regulation and promotes breast cancer cell invasion. J. Biol. Chem. 2012, 287, 21783-21795. [CrossRef] [PubMed]

66. Lieber, M.R.; Ma, Y.; Pannicke, U.; Schwarz, K. Mechanism and regulation of human non-homologous DNA end-joining. Nat. Rev. 2003, 4, 712-720. [CrossRef] [PubMed]

67. Zhu, F.; Liu, J.L.; Li, J.P.; Xiao, F.; Zhang, Z.X.; Zhang, L. MicroRNA-124 (miR-124) regulates Ku70 expression and is correlated with neuronal death induced by ischemia/reperfusion. J. Mol. Neurosci. 2014, 52, 148-155. [CrossRef] [PubMed]

68. Zhang, Z.Y.; Fu, S.L.; Xu, S.Q.; Zhou, X.; Liu, X.S.; Xu, Y.J.; Zhao, J.P.; Wei, S. By downregulating Ku80, HSA-miR-526b suppresses non-small cell lung cancer. Oncotarget 2015, 6, 1462-1477. [CrossRef] [PubMed] 
69. Ciccia, A.; Elledge, S.J. The DNA damage response: Making it safe to play with knives. Mol. Cell 2010, 40, 179-204. [CrossRef] [PubMed]

70. Neijenhuis, S.; Bajrami, I.; Miller, R.; Lord, C.J.; Ashworth, A. Identification of miRNA modulators to PARP inhibitor response. DNA Repair 2013, 12, 394-402. [CrossRef] [PubMed]

71. Mueller, A.C.; Sun, D.; Dutta, A. The miR-99 family regulates the DNA damage response through its target SNF2H. Oncogene 2013, 32, 1164-1172. [CrossRef] [PubMed]

72. Zhao, L.; Bode, A.M.; Cao, Y.; Dong, Z. Regulatory mechanisms and clinical perspectives of miRNA in tumor radiosensitivity. Carcinogenesis 2012, 33, 2220-2227. [CrossRef] [PubMed]

73. Kumar, M.; Lu, Z.; Takwi, A.A.; Chen, W.; Callander, N.S.; Ramos, K.S.; Young, K.H.; Li, Y. Negative regulation of the tumor suppressor p53 gene by microRNAs. Oncogene 2011, 30, 843-853. [CrossRef] [PubMed]

74. Hong, C.F.; Lin, S.Y.; Chou, Y.T.; Wu, C.W. MicroRNA-7 compromises p53 protein-dependent apoptosis by controlling the expression of the chromatin remodeling factor SMARCD1. J. Biol. Chem. 2016, 291, 1877-1889. [CrossRef] [PubMed]

75. Rosenfeld, N.; Aharonov, R.; Meiri, E.; Rosenwald, S.; Spector, Y.; Zepeniuk, M.; Benjamin, H.; Shabes, N.; Tabak, S.; Levy, A.; et al. MicroRNAs accurately identify cancer tissue origin. Nat. Biotechnol. 2008, 26, 462-469. [CrossRef] [PubMed]

76. Lu, J.; Getz, G.; Miska, E.A.; Alvarez-Saavedra, E.; Lamb, J.; Peck, D.; Sweet-Cordero, A.; Ebert, B.L.; Mak, R.H.; Ferrando, A.A.; et al. MicroRNA expression profiles classify human cancers. Nature 2005, 435, 834-838. [CrossRef] [PubMed]

77. Wang, W.; Wu, S.; Shi, Y.; Miao, Y.; Luo, X.; Ji, M.; Yao, K.; He, J. c-MYB regulates cell growth and DNA damage repair through modulating miR-143. FEBS Lett. 2015, 589, 555-564. [CrossRef] [PubMed]

78. Besse, A.; Sana, J.; Lakomy, R.; Kren, L.; Fadrus, P.; Smrcka, M.; Hermanova, M.; Jancalek, R.; Reguli, S.; Lipina, R.; et al. miR-338-5p sensitizes glioblastoma cells to radiation through regulation of genes involved in DNA damage response. Tumour Biol. 2016, 37, 7719-7727. [CrossRef] [PubMed]

79. Liu, S.; Pan, X.; Yang, Q.; Wen, L.; Jiang, Y.; Zhao, Y.; Li, G. MicroRNA-18a enhances the radiosensitivity of cervical cancer cells by promoting radiation-induced apoptosis. Oncol. Rep. 2015, 33, 2853-2862. [CrossRef] [PubMed]

80. Lynam-Lennon, N.; Reynolds, J.V.; Marignol, L.; Sheils, O.M.; Pidgeon, G.P.; Maher, S.G. MicroRNA-31 modulates tumour sensitivity to radiation in oesophageal adenocarcinoma. J. Mol. Med. 2012, 90, 1449-1458. [CrossRef] [PubMed]

81. Ebi, H.; Sato, T.; Sugito, N.; Hosono, Y.; Yatabe, Y.; Matsuyama, Y.; Yamaguchi, T.; Osada, H.; Suzuki, M.; Takahashi, T. Counterbalance between RB inactivation and miR-17-92 overexpression in reactive oxygen species and DNA damage induction in lung cancers. Oncogene 2009, 28, 3371-3379. [CrossRef] [PubMed]

82. Ohyashiki, K.; Umezu, T.; Yoshizawa, S.; Ito, Y.; Ohyashiki, M.; Kawashima, H.; Tanaka, M.; Kuroda, M.; Ohyashiki, J.H. Clinical impact of down-regulated plasma miR-92a levels in non-hodgkin's lymphoma. PLoS ONE 2011, 6, e16408. [CrossRef] [PubMed]

83. Ferrajoli, A.; Shanafelt, T.D.; Ivan, C.; Shimizu, M.; Rabe, K.G.; Nouraee, N.; Ikuo, M.; Ghosh, A.K.; Lerner, S.; Rassenti, L.Z.; et al. Prognostic value of miR-155 in individuals with monoclonal B-cell lymphocytosis and patients with B chronic lymphocytic leukemia. Blood 2013, 122, 1891-1899. [CrossRef] [PubMed]

84. Rebucci, M.; Michiels, C. Molecular aspects of cancer cell resistance to chemotherapy. Biochem. Pharm. 2013, 85, 1219-1226. [CrossRef] [PubMed]

85. He, J.; Yu, J.J.; Xu, Q.; Wang, L.; Zheng, J.Z.; Liu, L.Z.; Jiang, B.H. Downregulation of ATG14 by EGR1-miR152 sensitizes ovarian cancer cells to cisplatin-induced apoptosis by inhibiting cyto-protective autophagy. Autophagy 2015, 11, 373-384. [CrossRef] [PubMed]

86. Kastl, L.; Brown, I.; Schofield, A.C. miRNA-34a is associated with docetaxel resistance in human breast cancer cells. Breast Cancer Res. Treat. 2012, 131, 445-454. [CrossRef] [PubMed]

87. Xu, R.X.; Liu, R.Y.; Wu, C.M.; Zhao, Y.S.; Li, Y.; Yao, Y.Q.; Xu, Y.H. DNA damage-induced NF-kB activation in human glioblastoma cells promotes miR-181b expression and cell proliferation. Cell. Physiol. Biochem. 2015, 35, 913-925. [CrossRef] [PubMed]

88. Ren, J.; Chu, Y.; Ma, H.; Zhang, Y.; Zhang, X.; Zhao, D.; Li, Z.; Wang, J.; Gao, Y.E.; Xiao, L.; et al. Epigenetic interventions increase the radiation sensitivity of cancer cells. Curr. Pharm. Des. 2014, 20, 1857-1865. [CrossRef] [PubMed] 
89. Zhu, W.; Zhu, D.; Lu, S.; Wang, T.; Wang, J.; Jiang, B.; Shu, Y.; Liu, P. miR-497 modulates multidrug resistance of human cancer cell lines by targeting Bcl2. Med. Oncol. 2012, 29, 384-391. [CrossRef] [PubMed]

90. Fu, W.F.; Chen, W.B.; Dai, L.; Yang, G.P.; Jiang, Z.Y.; Pan, L.; Zhao, J.; Chen, G. Inhibition of miR-141 reverses cisplatin resistance in non-small cell lung cancer cells via upregulation of programmed cell death protein 4. Eur. Rev. Med. Pharm. Sci. 2016, 20, 2565-2572.

91. Samuel, P.; Pink, R.C.; Caley, D.P.; Currie, J.M.; Brooks, S.A.; Carter, D.R. Over-expression of miR-31 or loss of KCNMA1 leads to increased cisplatin resistance in ovarian cancer cells. Tumor Biol. 2016, 37, 2565-2573. [CrossRef] [PubMed]

92. Yang, W.; Wei, J.; Sun, T.; Liu, F. Effects of knockdown of miR-210 in combination with ionizing radiation on human hepatoma xenograft in nude mice. Radiat. Oncol. 2013, 8, 102. [CrossRef] [PubMed]

93. Ng, W.L.; Yan, D.; Zhang, X.; Mo, Y.Y.; Wang, Y. Over-expression of miR-100 is responsible for the low-expression of ATM in the human glioma cell line: M059J. DNA Repair 2010, 9, 1170-1175. [CrossRef] [PubMed]

94. Ye, C.; Sun, N.X.; Ma, Y.; Zhao, Q.; Zhang, Q.; Xu, C.; Wang, S.B.; Sun, S.H.; Wang, F.; Li, W. MicroRNA-145 contributes to enhancing radiosensitivity of cervical cancer cells. FEBS Lett. 2015, 589, 702-709. [CrossRef] [PubMed]

95. Lv, L.; Li, Y.; Deng, H.; Zhang, C.; Pu, Y.; Qian, L.; Xiao, J.; Zhao, W.; Liu, Q.; Zhang, D.; et al. miR-193a-3p promotes the multi-chemoresistance of bladder cancer by targeting the HOXC9 gene. Cancer Lett. 2015, 357, 105-113. [CrossRef] [PubMed]

96. Wouters, M.D.; van Gent, D.C.; Hoeijmakers, J.H.; Pothof, J. MicroRNAs, the DNA damage response and cancer. Mutat. Res. 2011, 717, 54-66. [CrossRef] [PubMed]

97. Czochor, J.R.; Glazer, P.M. MicroRNAs in cancer cell response to ionizing radiation. Antioxid. Redox Signal. 2014, 21, 293-312. [CrossRef] [PubMed]

98. Wu, Y.; Liu, G.L.; Liu, S.H.; Wang, C.X.; Xu, Y.L.; Ying, Y.; Mao, P. MicroRNA-148b enhances the radiosensitivity of non-hodgkin's lymphoma cells by promoting radiation-induced apoptosis. J. Radiat. Res. 2012, 53, 516-525. [CrossRef] [PubMed]

99. Wagner-Ecker, M.; Schwager, C.; Wirkner, U.; Abdollahi, A.; Huber, P.E. MicroRNA expression after ionizing radiation in human endothelial cells. Radiat. Oncol. 2010, 5, 25. [CrossRef] [PubMed]

100. Gwak, H.S.; Kim, T.H.; Jo, G.H.; Kim, Y.J.; Kwak, H.J.; Kim, J.H.; Yin, J.; Yoo, H.; Lee, S.H.; Park, J.B. Silencing of microRNA-21 confers radio-sensitivity through inhibition of the PI3K/AKT pathway and enhancing autophagy in malignant glioma cell lines. PLoS ONE 2012, 7, e47449. [CrossRef] [PubMed]

101. Chaudhry, M.A. Radiation-induced microRNA: Discovery, functional analysis, and cancer radiotherapy. J. Cell. Biochem. 2014, 115, 436-449. [CrossRef] [PubMed]

102. Chaudhry, M.A.; Sachdeva, H.; Omaruddin, R.A. Radiation-induced microRNA modulation in glioblastoma cells differing in DNA-repair pathways. DNA Cell Biol. 2010, 29, 553-561. [CrossRef] [PubMed]

103. Chaudhry, M.A. Real-time PCR analysis of micro-RNA expression in ionizing radiation-treated cells. Cancer Biother. Radiopharm. 2009, 24, 49-56. [CrossRef] [PubMed]

104. Weidhaas, J.B.; Babar, I.; Nallur, S.M.; Trang, P.; Roush, S.; Boehm, M.; Gillespie, E.; Slack, F.J. MicroRNAs as potential agents to alter resistance to cytotoxic anticancer therapy. Cancer Res. 2007, 67, 11111-11116. [CrossRef] [PubMed]

105. Saleh, A.D.; Savage, J.E.; Cao, L.; Soule, B.P.; Ly, D.; DeGraff, W.; Harris, C.C.; Mitchell, J.B.; Simone, N.L. Cellular stress induced alterations in microRNA let-7a and let-7b expression are dependent on p53. PLoS ONE 2011, 6, e24429. [CrossRef] [PubMed]

106. Marta, G.N.; Garicochea, B.; Carvalho, A.L.; Real, J.M.; Kowalski, L.P. MicroRNAs, cancer and ionizing radiation: Where are we? Rev. Assoc. Med. Bras. 2015, 61, 275-281. [CrossRef] [PubMed]

107. Novello, C.; Pazzaglia, L.; Conti, A.; Quattrini, I.; Pollino, S.; Perego, P.; Picci, P.; Benassi, M.S. p53-Dependent activation of microRNA-34a in response to etoposide-induced DNA damage in osteosarcoma cell lines not impaired by dominant negative p53 expression. PLoS ONE 2014, 9, e114757. [CrossRef] [PubMed]

108. Liu, J.; Zhu, H.; Yang, X.; Ge, Y.; Zhang, C.; Qin, Q.; Lu, J.; Zhan, L.; Cheng, H.; Sun, X. MicroRNA-21 is a novel promising target in cancer radiation therapy. Tumor Biol. 2014, 35, 3975-3979. [CrossRef] [PubMed]

109. Metheetrairut, C.; Slack, F.J. MicroRNAs in the ionizing radiation response and in radiotherapy. Curr. Opin. Genet. Dev. 2013, 23, 12-19. [CrossRef] [PubMed] 
110. Daige, C.L.; Wiggins, J.F.; Priddy, L.; Nelligan-Davis, T.; Zhao, J.; Brown, D. Systemic delivery of a miR34a mimic as a potential therapeutic for liver cancer. Mol. Cancer Ther. 2014, 13, 2352-2360. [CrossRef] [PubMed]

111. Conde, J.; Rosa, J.; de la Fuente, J.M.; Baptista, P.V. Gold-nanobeacons for simultaneous gene specific silencing and intracellular tracking of the silencing events. Biomaterials 2013, 34, 2516-2523. [CrossRef] [PubMed]

112. Shah, M.Y.; Ferrajoli, A.; Sood, A.K.; Lopez-Berestein, G.; Calin, G.A. MicroRNA therapeutics in cancer-An emerging concept. EBioMedicine 2016, 12, 34-42. [CrossRef] [PubMed]

(C) 2016 by the authors; licensee MDPI, Basel, Switzerland. This article is an open access article distributed under the terms and conditions of the Creative Commons Attribution (CC-BY) license (http://creativecommons.org/licenses/by/4.0/). 